\title{
“Tempus fugit". Giuseppe Mazzocchi y Vigo, en EL RECUERDO
}

\author{
Será biva siempre su grande grandeza, \\ su fe y su esperança y su caridad, \\ su vida et justicia, prudencia et bondad, \\ su grande templança y gran fortaleza. \\ Et aunque nos dé pesar la tristeza, \\ teniendo delante tan alta memoria, \\ la pena será menor que la gloria \\ por esta gran fama que dexa su alteza. ${ }^{1}$
}

Parece mentira, pero ha pasado ya algo más de un año desde que Giuseppe Mazzocchi (1960-2017), catedrático de Literatura Española de la Universidad de Pavía, nos ha dejado. Demasiado pronto, sin duda. Perdura, eso sí, el recuerdo del maestro y del amigo que con tanta generosidad y afecto nos brindó siquiera parte de su extraordinario y amplio conocimiento acerca de tantas y tantas disciplinas que ya lo habían convertido en un excelso humanista y, sin temor a exagerar, en uno de los medievalistas más reconocidos de su generación. También queda en la memoria el perfil del sabio poseedor de una vastísima erudición de la que ha dejado constancia en sus muy numerosas publicaciones sobre variado asunto, bien de cultura clásica, bien de diferentes literaturas peninsulares: catalana, gallego-portuguesa y, muy especialmente, española. Y siempre, y mucho más en las distancias cortas, queda asimismo en quienes tuvimos la fortuna de tratarlo la huella de un académico dotado de una especial habilidad para transmitir sus amplios conocimientos con extraordinaria facilidad elocutiva, con vehemencia, pe-

'Polo de Grimaldo, Elegía sobre la muerte del muy alto et muy católico príncipe et rey nuestro señor don Fernando, ed. Giuseppe Mazzocchi, Zaragoza: Diputación de ZaragozaInstitución Fernando el Católico, 1999, p. 47. 
ro también con esa dosis de humor, fina ironía y, cuando era preciso, hasta cierto sarcasmo que tanto le caracterizaban.

Sus vínculos con Vigo nacieron mucho antes de su primera visita a la ciudad y a las aulas de su universidad. Como me recordó en más de una ocasión, ya a comienzos de los años 80, y entre la correspondencia publicitaria que llegaba a las tiendas de ropa que sus padres regentaban, llegó a Pavía el eco de la movida viguesa; años más tarde, ya en el año I999, en su primera visita a nuestra ciudad, todavía recordaba perfectamente no solo el contexto económico y cultural que había favorecido el movimiento, sino también los nombres de la práctica totalidad de los muchos grupos, los títulos de sus creaciones y los locales que, todavía entonces, quiso visitar. $\mathrm{Y}$, precisamente, esa extraordinaria memoria y su capacidad por mostrar interés y curiosidad por todo fue otra de sus peculiaridades más acusadas, la misma que su afán por transmitirlo con enorme facilidad, hecho que le llevó a incluir también a nuestra ciudad y su entorno (Tuy, A Guarda, Valença) en parte del itinerario de una de las muchas rutas que como guía turístico "para viejos ricachones”, como gustaba decir, organizó por diferentes lugares de la Península.

Sin duda, lo que Giuseppe nos brindó a muchos de los investigadores vigueses fue mucho más que lo que pudo recibir. Sus visitas en diferentes ocasiones y por motivos diversos, siempre estuvieron acompañadas del generoso ofrecimiento no ya del material publicado por el equipo que tanto el profesor Giovanni Caravaggi, su maestro, como él mismo habían ido formando en la Universidad de Pavia (todos recordamos que buena parte de su equipaje la integraban ejemplares que repartía entre el auditorio de sus clases y conferencias), sino de su disposición, siempre sincera, para la correspondencia amistosa y el asesoramiento en las más variadas y, en ocasiones, intrincadas cuestiones ecdóticas planteadas, pero también para mediar en la consecución de tal o cual documento inaccesible para todos... ¡menos para 
él! Asimismo, las puertas de las sedes por las que transcurrió su vida académica, y muy especialmente las de Ferrara y Pavía, se abrieron a nuestros profesores y estudiantes gracias a sus gestiones, $\mathrm{y}$ diferentes promociones de investigadores vigueses pudieron familiarizarse con el método neolachmanniano gracias a los cursos estivales que, en torno a la crítica textual, celebró en diferentes sedes (Sevilla, Pavía y Santander), creando vínculos que se prolongaban más allá de los días lectivos.

Todavía en su última visita a nuestra facultad pudo inaugurar el, en aquel momento (noviembre de 20I4), recién iniciado programa de doctorado interuniversitario de Estudios Literarios, dejando prueba de su magisterio y de su bonhomía. Sé, porque así se nos transmitió, que aquellos días, que incluso quiso prolongar con Nora más allá de lo académico en nuestra ciudad, quedaron grabados para él; también para quienes tuvimos la fortuna de compartirlas. Poco imaginábamos entonces que sería su última estancia en nuestra ciudad.

Falta su presencia, que tanto echamos en falta, pero, por fortuna, además del recuerdo, scripta manent. Sirvan las páginas de este volumen como cálido homenaje al académico y al amigo.

Antonio Chas Aguión Universidad de Vigo 